\title{
Genetic structure of Lima bean (Phaseolus lunatus L.) landraces grown in the Mayan area
}

\author{
Luciana Camacho-Pérez · Jaime Martínez-Castillo • Javier O. Mijangos-Cortés • \\ Miriam M. Ferrer-Ortega · Jean Pierre Baudoin • Rubén H. Andueza-Noh
}

Received: 29 October 2016/ Accepted: 16 May 2017

(C) Springer Science+Business Media Dordrecht 2017

\begin{abstract}
Lima bean (Phaseolus lunatus L.) is an important crop in the Mayan culture. The Mayan area, considered as a main center of Mesoamerican diversity, has been divided into two subareas: the Mayan lowlands and the Mayan highlands. The Yucatan Peninsula is part of the Mayan lowlands and holds the highest number of Lima bean landraces of Mexico, but Lima beans are in high risk of genetic erosion due to intensification of the traditional Mayan agriculture. However, information on genetic diversity of Lima beans of the Mayan highlands is lacking. By using 46 landraces collected in the Mayan
\end{abstract}

L. Camacho-Pérez · J. Martínez-Castillo .

J. O. Mijangos-Cortés

Centro de Investigación Científica de Yucatán (CICY),

Calle 43 No. 130, Col. Chuburná de Hidalgo,

C.P. 97205 Mérida, Yucatán, Mexico

M. M. Ferrer-Ortega

Departamento de Manejo y Conservación de Recursos

Naturales Tropicales, Facultad de Medicina Veterinaria y

Zootecnia, Universidad Autónoma de Yucatán, Carretera

a Xmatkuil Km. 15.5, C.P. 97315 Mérida, Yucatán,

Mexico

J. P. Baudoin

Gembloux Agro-Bio Tech, University of Liège, Passage des Déportés, 2, 5030 Gembloux, Belgium

R. H. Andueza-Noh ( $ه)$

CONACYT-Instituto Tecnológico de Conkal, avenida tecnológico s/n Conkal, C.P. 97345 Conkal, Yucatán, Mexico

e-mail: r_andueza81@hotmail.com area (23 from each subarea) and 73 ISSR loci (intersimple sequence repeats), we analyzed the structure, diversity and genetic relationships of Lima beans of this part of Mesoamerica. High levels of diversity $\left(H_{\mathrm{BAY}}=0.45\right)$ and genetic structure $\left(F_{\mathrm{ST}}=0.66\right)$ were found for the whole Mayan area. Genetic diversity in the Mayan lowlands was apparently higher than the Mayan highlands $\left(H_{\mathrm{BAY}}=0.44\right.$ and 0.36 , respectively); but differences were not statistically significant. Genetic structure between the subareas was high (AMOVA $=30 \%$ of total variation), most landraces grouping according to their geographic origin. This study shows the importance of the Mayan culture in the diversification and conservation of Lima beans. The results provide important information that should be considered when implementing strategies to collect Lima bean landraces and planning in situ and ex situ programs to conserve these landraces in the Mayan region.

Keywords Genetic diversity - Insitu conservation . Lima bean · Mayan lowlands · Phaseolus lunatus

\section{Introduction}

Mesoamerica is one of the main centres of the origin of agriculture and domestication of plants of the world (Vavilov 1926; Ranere et al. 2009; Zizumbo-Villarreal and Colunga-GarcíaMarín 2010). One of the most 
important cultural areas of Mesoamerica is the Mayan region which has been divided into two subareas: (1) The Mayan lowlands, which includes the Yucatan Peninsula (Yucatan, Campeche and Quintana Roo) and the state of Tabasco in Mexico, the region of Peten in Guatemala and Belize; and (2) the Mayan highlands, which includes the state of Chiapas in Mexico, Guatemala (except Peten) and the western part of Honduras and El Salvador (Ruz 1981; Garza et al. 1996; Sharer 1999). Within the Mayan area, evidence has been found about domestication of regionally important species such as jocote (Spondias purpurea L; Miller and Schaal 2005), scarlet runner bean ( $P$. coccineus L.; Spataro et al. 2011) and Lima beans ( $P$. lunatus L.; Andueza-Noh et al. 2013).

The Mayan area possesses a high richness of plant genetic resources because many farmers still practice the traditional Mesoamerican agricultural system called milpa (Colunga-GarcíaMarín and May-Pat 1992; Zizumbo-Villarreal and Colunga-GarcíaMarín 2010). However, in recent decades, the Mayan milpa has undergone a process of intensification that has placed the system in crisis. As a result, some crops of great importance to Mayan farmers, such as the Lima beans landraces are at risk of genetic erosion (Martínez-Castillo et al. 2012).

Lima beans are the second most important cultivated species of Phaseolus in the world. It includes two botanical varieties: $P$. lunatus var. silvester Baudet and P. lunatus var. lunatus (Baudet 1977). Recent studies indicate the existence of three major gene pools within the species: the Andean (A), Mesoamerican I (MI) and Mesoamerican II (MII), all of which contain wild and domesticated forms (Serrano-Serrano et al. 2010, 2012; Martínez-Castillo et al. 2014). Lima beans cultivated in the Yucatán Peninsula are part of the MII gene pool, which constitutes the domesticated forms of Lima beans with the highest richness in the whole Mexico (Ballesteros 1999). Molecular studies have shown that the cultivated gene pool of Lima beans in the Yucatan Peninsula have high levels of genetic diversity (Martínez-Castillo et al. 2008, 2012). While the genetic diversity of Lima beans of the Mayan lowlands is well documented, information on Lima beans grown in the Mayan highlands is still poor, and only germplasm has been collected (Debouck 2011). Here we hypothesized that Lima bean of the Mayan area have a high genetic structure. Genetic diversity is greater in the Mayan lowlands than in the Mayan highlands, and there is a pattern of clustering based on these two Mayan subareas.

The inter-simple sequence repeats (ISSR) allows detection of polymorphism without previous knowledge of DNA sequences. This is a dominant molecular marker that involves amplification of DNA using a single primer composed of a microsatellite (SSR) sequence (Zietkiewicz et al. 1994). The ISSR markers are rapid, simple and cheap for assessing genetic diversity, structure, and relationships among cultivars (Martins et al. 2003; González et al. 2005; Culley et al. 2007). In this study, ISSR markers were used to analyze the structure and genetic diversity of the domesticated gene pool of Lima beans throughout the entire Mayan area to generate basic information for designing conservation policies to the species and its varieties in this important cultural region.

\section{Materials and methods}

\section{Plant material and DNA extraction}

Sampling included 46 accessions (23 from the Mayan lowlands and 23 from the Mayan highlands) (Fig. 1) from the collection of the International Center for Tropical Agriculture (CIAT, Cali, Colombia) and from the collection of Dr. Martínez-Castillo held at the Centro de Investigación Cientifica de Yucatan (CICY). Most accessions of Dr. Martínez-Castillo were collected directly from farmers either from milpas or barns; some were purchased on local markets. Data on the origin of the CIAT accessions were only available for few accessions (Table 1). Ten seeds of each accession were germinated in a greenhouse at the CICY. The DNA was extracted from five seedlings of each accession using the protocol of Dellaporta et al. (1983), and the quality was verified by electrophoresis in $1 \%$ agarose gel with $1 \mathrm{X}$ Trisborate-EDTA (1X TBE: $100 \mathrm{mM}$ Tris-borate, pH 8.0, $2 \mathrm{mM}$ EDTA) buffer and staining with ethidium bromide.

\section{ISSR analysis}

The inter-simple sequence repeat (ISSR) technique was used following the work by Martínez-Castillo et al. (2008). Each ISSR band was considered as an 


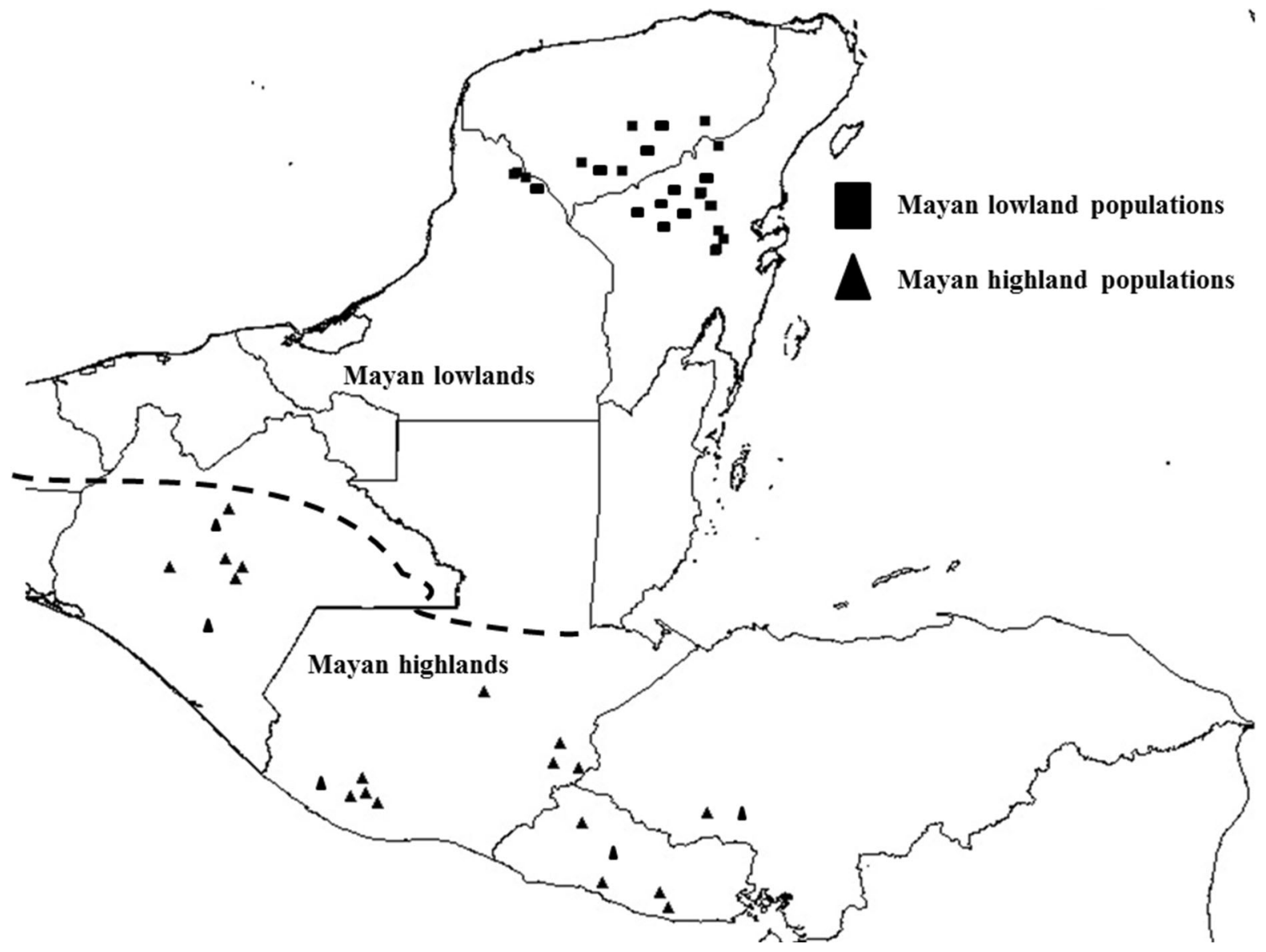

Fig. 1 Geographical distribution of Lima bean landraces collected in the Mayan area

independent locus and polymorphic bands were scored as absent (0) or present (1) for all samples. Four primers were used: $15(\mathrm{GACA})_{3} \mathrm{RG}, 16 \mathrm{YR}(\mathrm{GACA})_{3}$, $30(\mathrm{GACAC})_{3} \mathrm{AG}$ and 32 (CACAC) $)_{3} \mathrm{RG}$ and 73 ISSR loci were generated. PCR amplification was performed in a total reaction volume of $20 \mu \mathrm{L}$ containing $10 \mathrm{mM}$ Tris- $\mathrm{HCl}$ (pH 9.0), $50 \mathrm{mM} \mathrm{KCl}, 2 \mathrm{mM}$ $\mathrm{MgCl}_{2}, 200 \mu \mathrm{M}$ dNTP, $1 \mu \mathrm{M}$ of primer, 1 unit of Taq polymerase (Promega, Madison, WI), and $20 \mathrm{ng}$ of template DNA. Amplification was performed in a GeneAmp PCR System 9700 (Applied Biosystems, Foster City, CA, USA), under the following conditions: 4 min at $94{ }^{\circ} \mathrm{C}$ for initial denaturing; followed by 35 cycles of $2 \mathrm{~min}$ at $94{ }^{\circ} \mathrm{C}, 1 \mathrm{~min}$ at 42 or $54{ }^{\circ} \mathrm{C}$ (depending on the primer), and $2 \mathrm{~min}$ at $72{ }^{\circ} \mathrm{C}$; and a final extension of $5 \mathrm{~min}$ at $72{ }^{\circ} \mathrm{C}$. Formamide $(4 \mu \mathrm{L})$ containing $0.45 \%$ bromophenol blue and $0.25 \%$ xylene-cianol was then added to each reaction mixture, then $4 \mu \mathrm{L}$ of the reaction mixture was loaded onto
$6 \%$ nondenaturing $30: 1$ bis-acrylamide gels $(320 \times 380 \times 0.4 \mathrm{~mm})$ containing $3 \mathrm{M}$ urea and $1 \mathrm{X}$ TBE buffer (Zietkiewicz et al. 1994). A 123-bp molecular marker standard was included in each gel. Electrophoresis was carried out at $300 \mathrm{~V}$ (SQ3 Sequence Hoeffer), and the products of the amplification were visualized with silver staining (Bassam et al. 1991).

Data analysis

\section{Genetic structure}

The genetic structure was analyzed through two methods: (1) Wright's genetic differentiation index $\left(F_{\mathrm{ST}}\right)$ obtained with the program POPOGENE ver. 1.31 (Yeh and Boyle 1999); (2) a hierarchical analysis of molecular variance (AMOVA) considering three levels: (a) the whole Mayan area (including all 
Table 1 Geographic location of 23 cultivated accessions of the Mesoamerican gene pool of $P$. lunatus in the Mayan area included in the study

\begin{tabular}{|c|c|c|c|c|c|c|}
\hline Accession & Origin & $\begin{array}{l}\text { Municipality or } \\
\text { provincy }\end{array}$ & $\begin{array}{l}\text { Latitude } \\
(\mathrm{N})\end{array}$ & $\begin{array}{l}\text { Longitude } \\
\text { (O) }\end{array}$ & $\begin{array}{l}\text { Altitude } \\
\text { (msnm) }\end{array}$ & Collecting provenance \\
\hline Negro azcatlan $^{\mathrm{a}}$ & Chiapas & Bochil & $17^{\circ} 00^{\prime} 00^{\prime \prime}$ & $92^{\circ} 31^{\prime} 48^{\prime \prime}$ & 1200 & Germplasm bank \\
\hline Patashete $^{\mathrm{a}}$ & Chiapas & Soyalo & $16^{\circ} 32^{\prime} 23^{\prime \prime}$ & $92^{\circ} 32^{\prime} 59^{\prime \prime}$ & 1200 & Local market \\
\hline Trapichito $^{\mathrm{a}}$ & Chiapas & Sn. Cristobal las C. & $16^{\circ} 26^{\prime} 59^{\prime \prime}$ & $92^{\circ} 024^{\prime} 0^{\prime \prime}$ & 2127 & Local market \\
\hline $\mathrm{G} 25288^{\mathrm{a}}$ & Chiapas & Tuxtla Gutiérrez & $16^{\circ} 26^{\prime} 59^{\prime \prime}$ & $93^{\circ} 04^{\prime} 11^{\prime \prime}$ & 535 & Germplasm bank \\
\hline Patashete $^{a}$ & Chiapas & Villa de acala & $16^{\circ} 20^{\prime} 23^{\prime \prime}$ & $92^{\circ} 28^{\prime} 11^{\prime \prime}$ & 420 & Local market \\
\hline $\mathrm{G} 25564^{\mathrm{a}}$ & Chiapas & - & - & - & - & Germplasm bank \\
\hline $\mathrm{G} 25277^{\mathrm{a}}$ & El Salvador & Cuscatlan & $13^{\circ} 25^{\prime} 11^{\prime \prime}$ & $88^{\circ} 34^{\prime} 47^{\prime \prime}$ & 800 & Germplasm bank \\
\hline $\mathrm{G} 25570^{\mathrm{a}}$ & Chiapas & - & - & - & - & Germplasm bank \\
\hline $\mathrm{G} 25280^{\mathrm{a}}$ & El Salvador & La paz & $13^{\circ} 17^{\prime} 23^{\prime \prime}$ & $88^{\circ} 30^{\prime} 36^{\prime \prime}$ & 170 & Germplasm bank \\
\hline Chilipuca roja ${ }^{a}$ & El Salvador & La libertad & $13^{\circ} 24^{\prime} 00^{\prime \prime}$ & $89^{\circ} 10^{\prime} 48^{\prime \prime}$ & 965 & Local market \\
\hline $\mathrm{G} 25595^{\mathrm{a}}$ & El Salvador & Morazán & $13^{\circ} 27^{\prime} 36^{\prime \prime}$ & $88^{\circ} 02^{\prime} 59^{\prime \prime}$ & 400 & Germplasm bank \\
\hline Juruma $^{a}$ & El Salvador & Santa ana & $14^{\circ} 04^{\prime} 12^{\prime \prime}$ & $89^{\circ} 17^{\prime} 24^{\prime \prime}$ & 400 & Germplasm bank \\
\hline $\mathrm{G} 25285^{\mathrm{a}}$ & Guatemala & Alta verapaz & $15^{\circ} 17^{\prime} 23^{\prime \prime}$ & $90^{\circ} 11^{\prime} 23^{\prime \prime}$ & 1317 & Germplasm bank \\
\hline $\mathrm{G} 26305^{\mathrm{a}}$ & Guatemala & Chiquimula & $14^{\circ} 19^{\prime} 48^{\prime \prime}$ & $89^{\circ} 17^{\prime} 24^{\prime \prime}$ & 700 & Germplasm bank \\
\hline $\mathrm{G} 25240^{\mathrm{a}}$ & Guatemala & Escuintla & $14^{\circ} 15^{\prime} 35^{\prime \prime}$ & $91^{\circ} 10^{\prime} 12^{\prime \prime}$ & 1790 & Germplasm bank \\
\hline Chaparota $^{\mathrm{a}}$ & Guatemala & Huehuetenango & $15^{\circ} 12^{\prime} 36^{\prime \prime}$ & $91^{\circ} 10^{\prime} 48^{\prime \prime}$ & 1538 & Local market \\
\hline Ojo de pato $^{\mathrm{a}}$ & Guatemala & Jalapa & $14^{\circ} 22^{\prime} 48^{\prime \prime}$ & $89^{\circ} 26^{\prime} 23^{\prime \prime}$ & 750 & Local market \\
\hline $\mathrm{G} 25992^{\mathrm{a}}$ & Guatemala & Quetzaltenango & $14^{\circ} 30^{\prime} 00^{\prime \prime}$ & $91^{\circ} 18^{\prime} 36^{\prime \prime}$ & 765 & Germplasm bank \\
\hline $\mathrm{G} 26446^{\mathrm{a}}$ & Guatemala & Retalhuleu & $14^{\circ} 19^{\prime} 12^{\prime \prime}$ & $91^{\circ} 24^{\prime} 35^{\prime \prime}$ & 150 & Germplasm bank \\
\hline $\mathrm{G} 26297^{\mathrm{a}}$ & Guatemala & Suchitepequez & $14^{\circ} 20^{\prime} 59^{\prime \prime}$ & $91^{\circ} 16^{\prime} 48^{\prime \prime}$ & 600 & Germplasm bank \\
\hline $\mathrm{G} 25256^{\mathrm{a}}$ & Guatemala & Zacapa & $14^{\circ} 34^{\prime} 48^{\prime \prime}$ & $89^{\circ} 19^{\prime} 11^{\prime \prime}$ & 1230 & Germplasm bank \\
\hline $\mathrm{G} 26308^{\mathrm{a}}$ & Honduras & Intibuca & $14^{\circ} 10^{\prime} 11^{\prime \prime}$ & $88^{\circ} 09^{\prime} 00^{\prime \prime}$ & 1000 & Germplasm bank \\
\hline $\mathrm{G} 26444^{\mathrm{a}}$ & Honduras & Intibuca & $14^{\circ} 10^{\prime} 11^{\prime \prime}$ & $88^{\circ} 09^{\prime} 00^{\prime \prime}$ & 1000 & Germplasm bank \\
\hline $\mathrm{JMC} 1030^{\mathrm{b}}$ & Campeche & Calkini & $20^{\circ} 07^{\prime} 27^{\prime \prime}$ & $89^{\circ} 53^{\prime} 02^{\prime \prime}$ & 74 & Farmers milpas or barns \\
\hline $\mathrm{JMC} 1033^{\mathrm{b}}$ & Campeche & Calkini & $20^{\circ} 04^{\prime} 41^{\prime \prime}$ & $89^{\circ} 48^{\prime} 37^{\prime \prime}$ & 111 & Farmers milpas or barns \\
\hline $\mathrm{JMC} 1052^{\mathrm{b}}$ & Campeche & Nohalal & $20^{\circ} 06^{\prime} 31^{\prime \prime}$ & $89^{\circ} 54^{\prime} 25^{\prime \prime}$ & 63 & Farmers milpas or barns \\
\hline Rojo $^{b}$ & Campeche & - & - & - & - & Local market \\
\hline Chak chi ${ }^{\mathrm{b}}$ & Q. Roo & Felipe Carrillo P. & $19^{\circ} 48^{\prime} 49^{\prime \prime}$ & $88^{\circ} 06^{\prime} 48^{\prime \prime}$ & 22 & Farmers milpas or barns \\
\hline Bacalar $^{\mathrm{b}}$ & Q. Roo & Felipe Carrillo P. & $19^{\circ} 35^{\prime} 01^{\prime \prime}$ & $88^{\circ} 02^{\prime} 43^{\prime \prime}$ & 14 & Farmers milpas or barns \\
\hline Chak plano ${ }^{\mathrm{b}}$ & Q. Roo & Felipe Carrillo P. & $19^{\circ} 34^{\prime} 39^{\prime \prime}$ & $88^{\circ} 02^{\prime} 43^{\prime \prime}$ & 14 & Farmers milpas or barns \\
\hline Pool santo ${ }^{\mathrm{b}}$ & Q. Roo & Felipe Carrillo P. & $19^{\circ} 48^{\prime} 42^{\prime \prime}$ & $88^{\circ} 06^{\prime} 42^{\prime \prime}$ & 22 & Local market \\
\hline $\mathrm{Sac} \mathrm{Ib}^{\mathrm{b}}$ & Q. Roo & Felipe Carrillo P. & $19^{\circ} 55^{\prime} 00^{\prime \prime}$ & $88^{\circ} 13^{\prime} 00^{\prime \prime}$ & 26 & Farmers milpas or barns \\
\hline Balche $^{\mathrm{b}}$ & Q. Roo & Felipe Carrillo P. & $19^{\circ} 55^{\prime} 30^{\prime \prime}$ & $88^{\circ} 12^{\prime} 36^{\prime \prime}$ & 26 & Farmers milpas or barns \\
\hline Balam-pach ${ }^{\text {b }}$ & Q. Roo & Felipe Carrillo P. & $19^{\circ} 55^{\prime} 53^{\prime \prime}$ & $88^{\circ} 12^{\prime} 16^{\prime \prime}$ & 26 & Farmers milpas or barns \\
\hline Chak-uolis ${ }^{\mathrm{b}}$ & Q. Roo & Felipe Carrillo P. & $19^{\circ} 23^{\prime} 26^{\prime \prime}$ & $88^{\circ} 04^{\prime} 29^{\prime \prime}$ & 14 & Local market \\
\hline Box uolis ${ }^{\mathrm{b}}$ & Q. Roo & Felipe Carrillo P. & $19^{\circ} 29^{\prime} 21^{\prime \prime}$ & $87^{\circ} 59^{\prime} 40^{\prime \prime}$ & 15 & Farmers milpas or barns \\
\hline Box petch ${ }^{\mathrm{b}}$ & Q. Roo & Felipe Carrillo P. & $19^{\circ} 24^{\prime} 12^{\prime \prime}$ & $88^{\circ} 03^{\prime} 52^{\prime \prime}$ & 8 & Farmers milpas or barns \\
\hline Kan $\mathrm{Ib}^{\mathrm{b}}$ & Q. Roo & Solidaridad & $20^{\circ} 21^{\prime} 34^{\prime \prime}$ & $88^{\circ} 02^{\prime} 10^{\prime \prime}$ & 23 & Farmers milpas or barns \\
\hline Mulición ${ }^{b}$ & Q. Roo & Solidaridad & $20^{\circ} 21^{\prime} 29^{\prime \prime}$ & $88^{\circ} 02^{\prime} 17^{\prime \prime}$ & 23 & Farmers milpas or barns \\
\hline Xnuk $\mathrm{Ib}^{\mathrm{b}}$ & Yucatán & Peto & $20^{\circ} 07^{\prime} 34^{\prime \prime}$ & $88^{\circ} 55^{\prime} 22^{\prime \prime}$ & 35 & Farmers milpas or barns \\
\hline Negro $^{b}$ & Yucatán & Tekax & $20^{\circ} 12^{\prime} 13^{\prime \prime}$ & $89^{\circ} 17^{\prime} 58^{\prime \prime}$ & 37 & Farmers milpas or barns \\
\hline $\mathrm{Sac}^{\mathrm{b}}$ & Yucatán & Valladolid & $20^{\circ} 35^{\prime} 56^{\prime \prime}$ & $88^{\circ} 09^{\prime} 48^{\prime \prime}$ & 27 & Farmers milpas or barns \\
\hline Chak $^{\mathrm{b}}$ & Yucatán & Valladolid & $20^{\circ} 35^{\prime} 42^{\prime \prime}$ & $88^{\circ} 09^{\prime} 52^{\prime \prime}$ & 25 & Farmers milpas or barns \\
\hline
\end{tabular}


Table 1 continued

\begin{tabular}{|c|c|c|c|c|c|c|}
\hline Accession & Origin & $\begin{array}{l}\text { Municipality or } \\
\text { provincy }\end{array}$ & $\begin{array}{l}\text { Latitude } \\
\text { (N) }\end{array}$ & $\begin{array}{l}\text { Longitude } \\
\text { (O) }\end{array}$ & $\begin{array}{l}\text { Altitude } \\
\text { (msnm) }\end{array}$ & Collecting provenance \\
\hline $\mathrm{X}$-mejen ${ }^{\mathrm{b}}$ & Yucatán & Yaxcaba & $20^{\circ} 32^{\prime} 52^{\prime \prime}$ & $88^{\circ} 49^{\prime} 39^{\prime \prime}$ & 7 & Farmers milpas or barns \\
\hline Madza-kitam ${ }^{\text {b }}$ & Yucatán & - & - & - & - & Local market \\
\hline Putsica-sutsuy ${ }^{\mathrm{b}}$ & Yucatán & - & - & - & - & Local market \\
\hline
\end{tabular}

a From the Mayan highlands

b From the Mayan lowlands

accessions), (b) between Mayan subareas (23 accessions from the Mayan lowlands and 23 from the Mayan highlands) and (c) between accessions in each subareas (including 115 individuals for each subarea), using the program Arlequin 2.0 (Excoffier et al. 2006). Long term Gene flow $(\mathrm{Nm})$ was also calculated using the program POPGENE ver. 1.31 (Yeh and Boyle 1999).

\section{Genetic relationships}

To analyze the genetic relationships among landraces of the Mayan area, the genetic data were analyzed using Bayesian clustering approaches as implemented in the program STRUCTURE (Pritchard et al. 2000) to infer the number of $K$ groups (i.e., populations or accessions). We used the admixture model with uncorrelated allele frequencies. Ten independent simulations were run for each value of $\mathrm{K}$ ranging from $\mathrm{K}=1$ to $\mathrm{K}=5$. The analyses were made with replications for a burn-in period of 10,000 and a run length of 100,000 . With the results generated, the optimal value of $\mathrm{K}$ was determined according to Evanno et al. (2005) using the program Structure Harvester v. 0.6.93 (Earl and VonHoldt 2012). Finally, the graphs of ancestry for the optimum value of $\mathrm{K}$ were generated using STRUCTURE. Thereafther a dendrogram with the neighbor joining method $(\mathrm{NJ})$ as implemented with the programs NEIGHBOR and CONSENSE in the Phylip package (Felsenstein 2005) was performed. The NJ was constructed using Nei's genetic distance (D) (Lynch and Milligan 1994) obtained with the program AFLP-SURV ver. 1.0 (Vekemans 2002) with 1000 bootstrap replicates. The dendrogram was visualized using the program TREEVIEW (Page 1996). Finally, we carried out a principal coordinate analysis (PCoA) using the program GenAlex 6 (Peakall and Smouse 2006). This technique allows us to explore the genetic structure of the sample data without a priori criteria, using each allele as an independent variable.

\section{Genetic diversity}

The ISSR is a dominant molecular marker, and unlike for codominant markers, estimating allele frequencies poses some difficulties (Lynch and Milligan 1994). These problems have been solved in numerous studies using Bayesian methods (Zhivotovsky 1999); and better estimators for analyzing dominant markers (Lynch and Milligan 1994; Krauss 2000). In this study, genetic diversity was estimated at two geographic levels: (a) Mayan area and b) Mayan subareas. To avoid common problems associated with the analysis of dominant data (Lynch and Milligan 1994; Culley and Wolfe 2001), we did not use HardyWeinberg equilibrium (HWE) in the analyses because domesticated populations of $P$. lunatus from the Yucatan Peninsula are known to deviate from Hardy-Weinberg equilibrium with co-dominant microsatellite markers (Martínez-Castillo 2005). Assumptions included absence of co-migration of alleles from different loci, alleles shared by two individuals descended from a common ancestor and each locus consisted of only two alleles that follow Mendelian inheritance (Martínez-Castillo et al. 2008). The polymorphic loci percentage $(\% \mathrm{P})$ was calculated with the program POPGENE ver. 1.31 (Yeh and Boyle 1999). Although Hardy-Weinberg equilibrium was not considered applicable in this study, on the basis of the results of Kremer et al. (2005), we decided to evaluate average heterozygosity ( $\left.H_{\mathrm{BAY}}\right)$ using the Bayesian approach proposed by Zhivotovsky (1999). This estimator was obtained with AFLP-SURV ver.1.0 program (Vekemans 2002). Paired Student $t$ tests were performed to compare the diversity values 
$\left(H_{\mathrm{BAY}}\right)$ between the two Mayan subareas $(\alpha=0.05)$ using the program Statgraphics ver. 15.2.06 (StatPoint 2006).

\section{Results}

\section{Genetic structure}

Genetic structure in whole Mayan area and in its two subareas is shown in Table 2. The Mayan area presented high genetic differentiation $\left(F_{\mathrm{ST}}=0.66\right.$, AMOVA: $65 \%$ of total variation was found between accessions). At the subarea level, the Mayan lowlands presented higher genetic structure $\left(F_{\mathrm{ST}}=0.63\right)$ and lower gene flow $(\mathrm{Nm}=0.25)$ than the Mayan highlands $\left(F_{\mathrm{ST}}=0.53, \mathrm{Nm}=0.34\right)$. Values for genetic differentiation between subareas and between accessions within each subarea were high (30 and 34\%, respectively; Table 3).

Genetic relationships

The Bayesian approach indicated that the optimum $\mathrm{K}$ was 2, indicating the existence of two genetically distinct groups (Fig. 2). The bar graphs in Fig. 3 show the coefficients of membership for each of the 46 accessions analyzed. Individuals of the Mayan lowlands belonged to one group and individuals of the Mayan highlands formed the other group. In Fig. 3, also can be show the existence of some accessions with some degree of ancestry from both groups.

Figure 4 shows the general pattern of grouping based on the two Mayan subareas. One group included 19 of the 23 accessions collected in the Mayan lowlands and had high bootstrap support $(88 \%)$. The other group included 23 accessions collected in the Mayan highlands

Table 2 Estimators of structure $\left(F_{\mathrm{ST}}\right)$ and gene flow $(\mathrm{Nm})$ of Mesoamerican gene pool of $P$. lunatus cultivated in the Mayan area, using 75 ISSR loci

\begin{tabular}{lll}
\hline Region & $F_{\mathrm{ST}}$ & $\mathrm{Nm}$ \\
\hline Whole Mayan area & $0.66(0.007)$ & 0.29 \\
Mayan lowlands & $0.63(0.021)$ & 0.25 \\
Mayan highlands & $0.53(0.008)$ & 0.34 \\
\hline
\end{tabular}

$F_{\text {ST }}$ genetic differentiation index assuming Hardy-Weinberg equilibrium

$P<0.5 \%$ and 3 accessions belonging to Mayan lowlands with bootstrap support (79\%). Six accessions were not grouped based on their geographical origin: accession G25240 collected in the Mayan highlands grouped with the Mayan lowlands accessions and the Bacalar, Trapichito, JMC 1030, JMC 1033 and JMC 105 accessions collected in the Mayan lowlands grouped with the Mayan highlands accessions.

The principal coordinate analysis (PCoA; Fig. 5) showed a pattern consistent with the NJ results. The presence of two groups were observed, with most individuals collected in the lowlands (gray triangles) grouped closer together than with individuals collected in the highlands (black squares). PCoA showed a greater dispersion of individuals in the highlands than in the lowlands, and some individuals of the Mayan lowlands were clustered with individuals collected in the highlands. These PCoA results were supported by 70 and $18 \%$ of the total variation accumulated in axis 1 and 2, respectively (Fig. 5).

\section{Genetic diversity}

The results generated by the structure (Figs. 2 and 3), NJ and PCoA analyses supported the existence of the two groups corresponding to the Mayan subareas. Based on this information, we analyzed the genetic diversity for all the Mayan area and within each of the two subareas.

The four primers ISSR generated 75 loci, which were all polymorphic. Primer $30(\mathrm{GACAC})_{3} \mathrm{AG}$, yielded the highest number of loci (21). The Mayan area level had $100 \%$ of the polymorphic loci $(\% \mathrm{P})$ and high levels of genetic diversity $\left(H_{\mathrm{BAY}}=0.44\right)$. At the Mayan subarea level, the percentage of polymorphic loci was slightly higher in the Mayan highlands than in the Mayan lowlands $(\% \mathrm{P}=100 \%$ and $97.33 \%$, respectively). The estimator $H_{\mathrm{BAY}}$ was higher in the Mayan lowlands than in the Mayan highlands (0. 44 and 0.36, respectively; Table 4), but the difference was not statistically significant.

\section{Discussion \\ Genetic structure of Lima beans landraces from the Mayan area}

$\mathrm{Nm}$ estimates indicate that the average number of successful immigrants per generation should be 
Table 3 Analysis of molecular variance (AMOVA) applied to Mesoamerican gene pool of P. lunatus cultivated in the Mayan area using 75 ISSR loci

\begin{tabular}{lcccc}
\hline Source of variation & Degrees of freedom & Sum of squares & Variance components & Variation percentage \\
\hline Within subareas & 1 & 649.701 & $5.91632^{* *}$ Va & 30.63 \\
Among accessions within subareas & 44 & 1611.765 & $6.65643^{* *} \mathrm{Vb}$ & 34.47 \\
Total & 206 & 3346.599 & 19.31271 & 65.10 \\
\hline
\end{tabular}

** Significant at $P<0.0001$

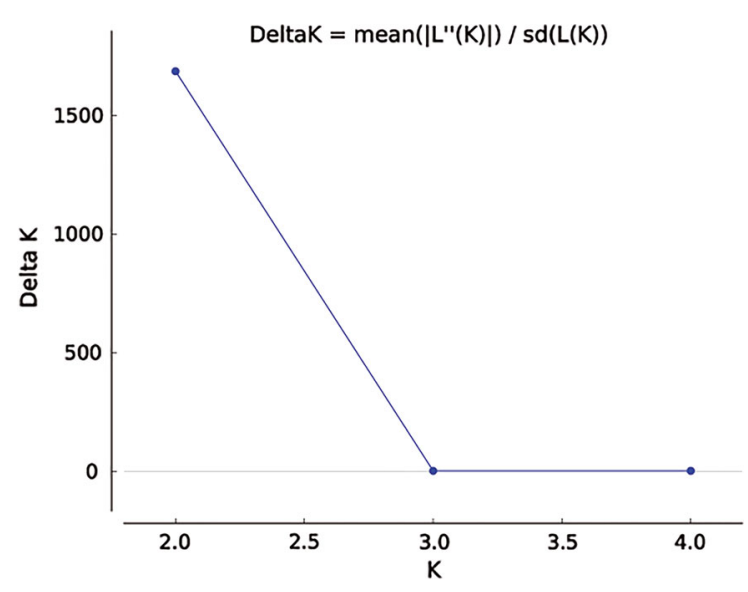

Fig. 2 Estimating number of subpopulations using delta $\mathrm{K}$ values for $\mathrm{K}$ ranging from 1 to 5 using method proposed by Evanno et al. (2005)

estimated in one to favour the reduction of population structure (Slatkin and Barton 1989). The high genetic structure observed in the Mayan area can be a consequence of the low level of long term gene flow found $(\mathrm{Nm}=0.29)$. It is generally accepted that gene flow is an important component of population structure (Slatkin 1994). Maquet et al. (1996) reported high genetic differentiation $\left(G_{\mathrm{ST}}=0.803\right)$ and very low gene flow $(\mathrm{Nm}=0.056)$ between wild populations of Lima bean distributed throughout the Central Valley of Costa Rica. Martínez-Castillo et al. (2007) reported $N m=0.28$ between wild and cultivated populations of Lima beans from the Yucatan Peninsula. Castiñeiras et al. (2007) using AFLP markers reported $G_{\mathrm{ST}}=0.23$ for cultivated accessions in three regions from Cuban home gardens. Montero-Rojas et al. (2013) using SSR molecular markers reported $G_{\mathrm{ST}}=0.036$ in 50 landraces collected directly in Haiti, Puerto Rico and Dominican Republic. With the exception of the results of Montero-Rojas et al. (2013), our results are consistent with those previously reported, indicating the existence of high genetic structure within the cultivated gene pool of Lima beans. The mating system and life history traits of a species are usually highly associated with differences in $G_{\mathrm{ST}}$ values (Hamrick et al. 1991). Hamrick et al. (1991) classified 473 taxa using eight characters of the species including life history traits, geographic range, mating system, mechanism of seed dispersal and reproductive method and reported $G_{\mathrm{ST}}=0.51$ for autogamous species. These results indicate that the high levels of genetic structure found in Lima beans is due to its predominantly autogamous reproductive system (Maquet et al. 1997; Webster et al. 1979).
Fig. 3 Tests of assignment of individuals showing clustering of 46 accessions of Lima bean based on analysis of genotypic data using STRUCTURE. Each accession is represented by a vertical bar

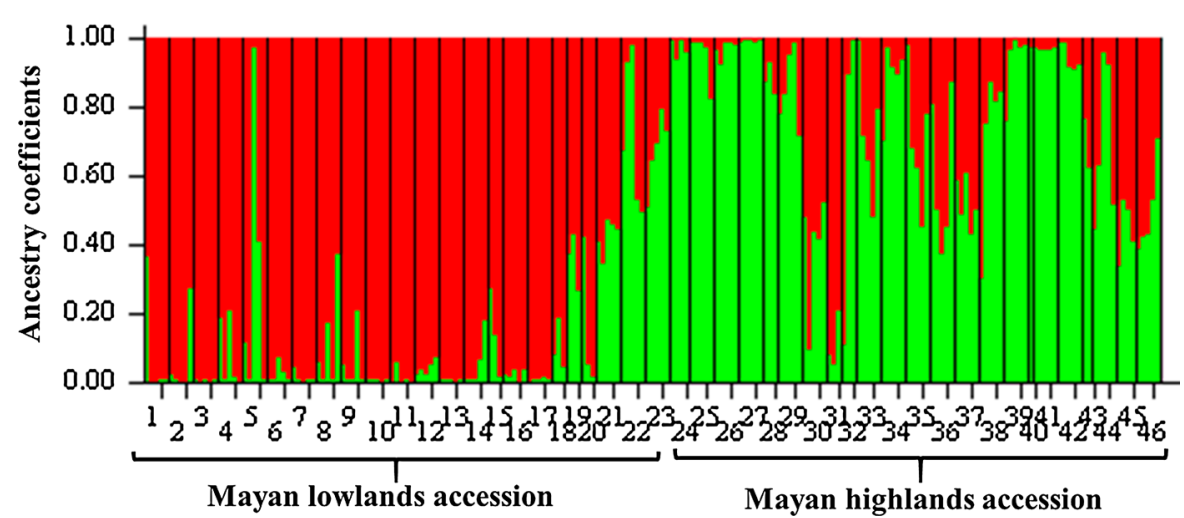




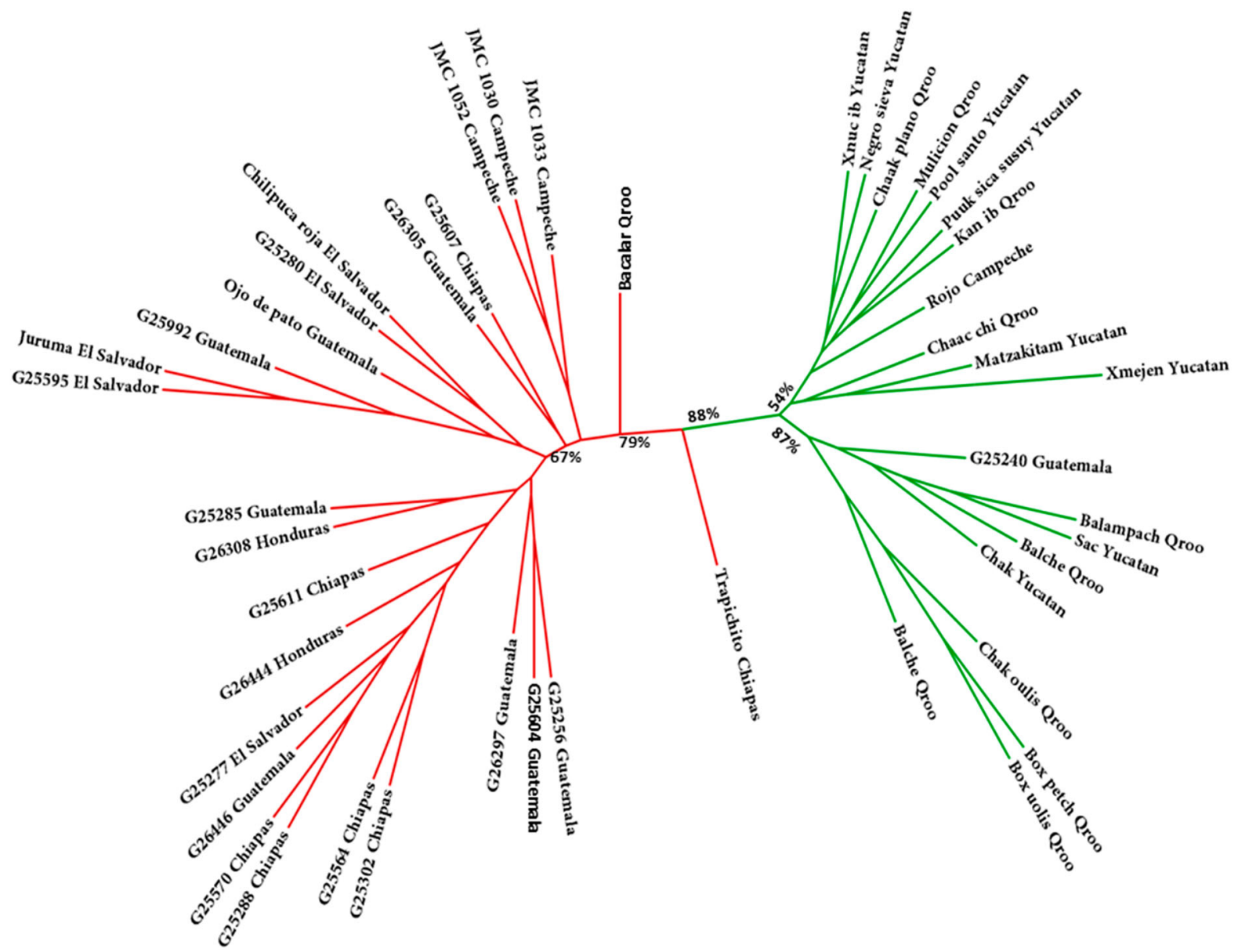

Fig. 4 Neighbor joining (NJ) analysis of 46 populations of Phaseolus lunatus cultivated in the Mayan area. Numbers at the nodes indicate percentage bootstrap support

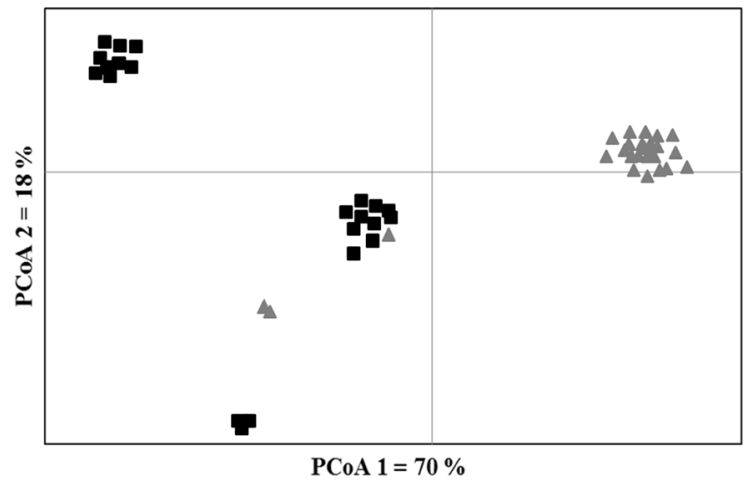

Fig. 5 Principal coordinate analysis (PCoA) of the populations of Phaseolus lunatus collected in the Mayan area. Black squares: highland populations, gray triangle: lowland populations
Genetic differentiation was high between the two Mayan subareas and between accessions within each subarea. The lowland accessions presented a higher genetic structure than the highland $\left(F_{\mathrm{ST}}=0.63\right.$ vs. 0.53 , respectively), which could be explained by the difference between gene flow levels found in the highland $(\mathrm{Nm}=0.34)$ and lowland $(\mathrm{Nm}=0.25)$ subareas (Table 2). Another factor that could explain the genetic structure observed within each subarea is the presence of landraces from the Papa and Sieva cultigroups in the Mayan lowlands (Martínez-Castillo et al. 2004) and landraces from the sole Sieva cultigroup in the Mayan highlands. Fofana et al. (1997) indicated that both cultigroups are involved in a recent process of sympatric speciation that eventually will generate a greater degree of genetic differentiation among them. The level of genetic differentiation 
Table 4 Estimators of genetic diversity of $P$. lunatus cultivated in the Mayan area measured at three levels

\begin{tabular}{lll}
\hline Level of study & $P_{\mathrm{p}}(\%)$ & $H_{\mathrm{BAY}}(\mathrm{SE})$ \\
\hline Whole Mayan area & 100 & $0.45(0.01)$ \\
Mayan lowlands & 97.33 & $0.44(0.01)$ \\
Mayan highlands & 100 & $0.36(0.01)$ \\
\hline
\end{tabular}

$P_{p}(\%)$ percentage of polymorphic loci, $H_{\mathrm{BAY}}$ average heterozygosity proposed by Zhivotovsky (1999), SE standard error

found in the Mayan lowlands in the present study was higher than the value reported by Martínez-Castillo et al. (2007) $F_{\mathrm{ST}}=0.63$ versus $G_{\mathrm{ST}}=0.47$ respectively. The discrepancy between current and previous results can be explained by the differences such as the molecular marker used; Martínez-Castillo et al. (2007) used SSR markers, and we used ISSR markers. The ISSR markers have a higher level of polymorphisms than do the SSR markers in landraces of Lima bean (Martínez-Castillo et al. 2008). In addition, more accessions and loci were analyzed in the present study.

Genetic relationships among landraces of Lima bean

The analysis of genetic relationships, with some exceptions, showed a general grouping pattern according to the two Mayan subareas. Exceptions to this pattern of clustering were five accessions that belonged to the lowlands and were grouped with accessions from the highlands of Guatemala and Chiapas. Even though there are no studies on the seed flow between lowland and highland Mayan communities, the discrepancies observed in five accessions could have been common in recent decades as a result of the displacement of Mayan peasants from the highlands (Chiapas and Guatemala) to the lowlands, promoting the flow and exchange of seeds among farmers from each subarea. Martínez-Castillo et al. (2004) reported a similar scenario in a study of the genetic diversity of landraces of Lima bean in the Yucatan Peninsula.

The clustering pattern observed using $\mathrm{NJ}$ and PCoA was supported by the high level of genetic structure and low levels of gene flow observed in the wide Mayan area. These results are similar to those found by Martínez-Castillo (2005), who used SSR markers and found that the wild and domesticated populations of $P$. lunatus present in the Yucatan Peninsula are grouped according to the region where they were collected. This pattern was concluded to be the result of low levels of gene flow and an isolation by distance.

Genetic diversity of Lima bean landraces grown in the Mayan area

Considering the hypothesis that the Mayan area is an important center of genetic diversity for Lima bean, we need to evaluate our results in relation to those reported by others, but with caution given that these other studies used different methodologies (e.g., estimates of diversity, molecular markers, sampling methods). Hamrick et al. (1991) in a review of the diversity and genetic structure of 473 taxa reported mean $H_{\mathrm{E}}=0.149$ and $H_{\mathrm{E}}=0.12$ for species with a mixed mating system and for short-lived perennials respectively. Using RAPD markers, Nienhuis et al. (1995) reported $H_{\mathrm{E}}=0.11$ for 35 accessions belonging to Mesoamerican landraces obtained from CIAT germplasm bank. Maquet et al. (1997) using allozymes reported $H_{\mathrm{E}}=0.26$ for a base collection of $P$. lunatus from the CIAT germplasm bank. Lioi et al. (1998) reported $H_{\mathrm{E}}=0.13$ for 60 cultivated accessions that included both Mesoamerican and Andean landraces. Castiñeiras et al. (2007), using AFLP markers, reported $H_{\mathrm{T}}=0.13$ for 65 cultivated accessions from Cuba. Montero-Rojas et al. (2013) reported $H_{\mathrm{E}}=0.337$ and $H_{\mathrm{O}}=0.403$ for 50 landraces collected directly from Haiti, Puerto Rico and the Dominican Republic.

Comparing our results with the studies referred to above, we consider that the Mayan area had high levels of genetic diversity. However, it is important to remember that some studies (Nienhuis et al. 1995; Maquet et al. 1997; Lioi et al. 1998) used accessions from seed banks, and management of germplasm held in seed banks can induce high levels of genetic erosion, starting with the sampling process and continuing with the seed regeneration (Gómez-Campo 2006; Maquet et al. 1997; Parzies et al. 2000). In our study, all accessions analyzed from lowland were collected directly from the farmers' milpas, which tend to favor the conservation of higher genetic diversity levels and could explain our high values. The importance of using accessions collected in situ for studies of genetic diversity is also reflected in the 
work of Montero-Rojas et al. (2013) and AnduezaNoh et al. (2013) who reported high levels of genetic diversity in landraces from the Carribean and throughout Mesoamerica, respectively.

With respect to the Mayan subareas, high values of genetic diversity were observed, with higher level in the lowlands (Table 4), but these differences were not significant. However, the values of $H_{\mathrm{BAY}}$ in favor of lowlands indicate the importance of this region of Mexico as a center of genetic diversity for the gene pool of cultivated Lima beans, even considering recent reports of genetic erosion of this gene pool. Camacho-Pérez (2009) and MartínezCastillo et al. (2012) reported that this crop experienced a high degree of genetic erosion from 1979 to 2007 in northeastern Campeche as a result mainly, of the incorporation of small farmers into the market and the introduction of improved varieties of Lima beans into this region. Unfortunately, there are no studies in the Mayan highlands to analyze and understand the factors that generated the lower levels of genetic diversity.

One factor that could explain the differences in genetic diversity among the two subareas is the presence of landraces belonging to two cultigroups, Papa and Sieva in the lowlands compared with landraces only from the Sieva cultigroup in the highlands. Also, gene flow and genetic introgression demonstrated between wild and cultivated Lima bean populations present in the Mayan area could explain these differences (Martínez-Castillo et al. 2007). Dzul-Tejero et al. (2014) analyzed the genetic introgression wild-cultivated in three milpas from the Yucatan Peninsula, finding that the milpa had higher levels of genetic introgression and genetic diversity. In addition, in both studies cited, weedy populations of Lima bean that were present could act as genetic bridges between wild and domesticated gene pools. In the Mayan highlands, however, there are no reports of flow and genetic introgression in Lima bean because wild populations of $P$. lunatus in the Mayan area grow only at low altitudes (Serrano-Serrano et al. 2010; Andueza-Noh et al. 2013). Certainly, genetic introgression remains an important factor in increasing the genetic diversity of crops (Arnold 1992; Quiros et al. 1992; Altieri and Montecinos 1993; Zizumbo-Villarreal et al. 2005).

Levels of genetic diversity found in the Lima beans grown in the lowlands (Table 4) were higher than those reported by Martínez-Castillo et al. (2008) $\left(\% \mathrm{P}=78.9, H_{\mathrm{BAY}}=0.31\right)$. Two aspects may explain the differences between their study and ours: (1) we analyzed a more complete geographical representation of germplasm, and (2) we analyzed five individuals per accession independently, while Martínez-Castillo et al. (2008) analyzed five individuals per accession in the form of genetic mixing, which could have resulted in a loss of information. Although the studies differed in the values of genetic diversity, they both point to the Mexican side (Mayan area) of the Yucatan Peninsula as an important center of genetic diversity for this crop.

Implications for conservation

The Mayan area has been identified as an important center of genetic diversity and domestication of Lima beans (Martínez-Castillo et al. 2008; Andueza-Noh et al. 2013); yet, in recent years, the landraces of this region, particularly in the Mayan lowlands, are at high risk of genetic erosion mainly from changes in traditional agriculture and market preferences that have led many farmers to abandon the cultivation of these landraces (Martínez-Castillo et al. 2008, 2012). Analyzing the results of previous studies (MartínezCastillo et al. 2004, 2008, 2012) with regard to our results, we can see that, despite the recent loss of landraces in the Mayan lowlands, levels of genetic diversity in the Mayan area are still high, highlighting the importance of the Mayan culture in generating and preserving crops with high levels of genetic diversity. On the premise that the reduction in genetic diversity of landraces is a worldwide problem and poses a high risk for the food security of future generations, the high genetic diversity within landraces highlights the need for management strategies that allow us to retain the widest possible set of landraces to ensure the maintenance of this genetic diversity within this important cultural region where the Lima bean is the second most important food legume in the genus Phaseolus.

Although the results generated in this study are of great importance for the conservation of $P$. lunatus in the Mayan area, more studies are needed to address the problems facing Lima beans in the traditional agricultural system of the Mayan highlands and better implement programs for the ex situ and in situ conservation throughout the Mayan area and avoid 
the loss of landraces of this species, ensuring future increases in the genetic and biological diversity in modern crops. We thus recommend in situ collections of Lima bean in the Mayan highlands and an ethnobotanical study of the species in the Mayan highlands to assess production dynamics. In this sense, as part of a program of ex situ conservation, the populations collected in this study have been deposited in the gene bank of the Centro de Investigacion Cientifica de Yucatan Mexico (CICY), and a copy was sent to the gene bank of the Sistema Nacional de Recursos Fitogenéticos para la Alimentación y la Agricultura (SINAREFI), to ensure their conservation and sustainable use. Finally, the results revealed that ISSR markers could be used as a reliable method to assess the genetic diversity in Lima bean germplasm and may help to identify or to select groups of genotypes with desirable characters. To generate diversification of landraces of Lima bean in both gene pools analyzed, we recommend that these 46 genotypes be used with efficient hybridization techniques to increase the levels of genetic polymorphism in Lima bean landraces in the Mayan region.

Acknowledgements The first author thanks the Consejo Nacional de Ciencia y Tecnología-Mexico for a scholarship for his postgraduate studies and Ciencia Básica-CONACYT (project number 54788) for financial support for the research and Julian Coello-Coello for technical support.

\section{Compliance with ethical standards}

Conflict of interest The authors declare that they have no conflict of interest.

\section{References}

Altieri MA, Montecinos C (1993) Conserving crop genetic resources in Latin America through farmer's participation. In: Christopher S, Potter DJ, Cohen JI (eds) Perspectives on biodiversity: case studies of genetic resource conservation and development. American Association for the Advancement of Science, Washington, pp 45-64

Andueza-Noh RH, Serrano-Serrano ML, Chacón Sánchez MI, Sánchez del Pino I, Camacho-Pérez L, Coello-Coello J, Mijangos Cortés J, Debouck DG, Martínez-Castillo J (2013) Multiple domestications of the mesoamerican gene pool of Lima bean (Phaseolus lunatus L.): evidence from chloroplast dna sequences. Genet Resour Crop Evol 60:1069-1086. doi:10.1007/s10722-012-9904-9

Arnold ML (1992) Natural hybridization as an evolutionary process. Annu Rev Ecol Syst 23:237-261. doi:10.1146/ annurev.es.23.110192.001321
Ballesteros G (1999) Contribuciones al conocimiento del frijol Lima (Phaseolus lunatus) en América Tropical. Dissertation, Colegio de Posgraduados, Mexico state

Bassam BJ, Anollés GC, Gresshoff PM (1991) Fast and sensitive silver staining of DNA in polyacrylamide gels. Anal Biochem 196:80-83. doi:10.1007/BF02788051

Baudet JC (1977) The taxonomic status of the cultivated types of Lima bean (Phaseolus lunatus L.). Trop Grain Legume Bull 7:29-30

Camacho-Pérez L (2009) Análisis de la erosión genética en variedades del ib (Phaseolus lunatus L.) del Noreste de Campeche, México. Dissertation. Universidad Autónoma de Yucatán, Mérida, Yucatán, México

Castiñeiras L, Guzmán F, Duque M, Shagarodsky T, Cristobal R, Carmen M (2007) AFLPs and morphological diversity of Phaseolus lunatus L. in Cuban home gardens: approaches to recovering the lost ex situ collection. Biodivers Conserv 16:2847-2865. doi:10.1007/s10531-006-9025-X

Colunga-GarcíaMarín P, May-Pat F (1992) El sistema milpero y sus recursos fitogenéticos. In: Zizumbo VD, Ramussen CH, Arias RLM, Terán CS (eds) La modernización de la milpa en Yucatán: utopía o realidad CICY-DANIDA. Mérida, Yucatán, México, pp 97-144

Culley TM, Wolfe AD (2001) Population genetic structure of the cleistogamous plant species Viola pubescens, as indicated by isozyme and ISSR molecular markers. Heredity 86:545-556. doi:10.1046/j.1365-2540.2001.00875.x

Culley TM, Sbita SJ, Wick A (2007) Population genetic effects of urban habitat fragmentation in the perennial herb Viola pubescens (Violaceae) using ISSR Markers. Ann Bot 100:91-100

Debouck DG (2011) Cahiers de phaseologie: Section Paniculati. CIAT, Cali, Colombia, p335.http://isa.ciat.cgiar.org/urg/ showunitfiles.do?type $=$ unitfiles \&category $=$ unitfiles \&by= collection

Dellaporta S, Wood J, Hicks J (1983) A plants DNA minipreparation: versión II. Plant Mol Biol Rep 1:19-21. doi:10.1007/BF02712670

Dzul-Tejero F, Coello-Coello J, Martínez-Castillo J (2014) Wild to crop introgression and genetic diversity in Lima bean (Phaseolus lunatus L.) in traditional Mayan milpas from Mexico. Conserv Genet 15:1315-1328. doi:10.1007/ s10592-014-0619-7

Earl DA, Vonholdtb M (2012) Structure harvester: a website and program for visualizing structure output and implementing the Evanno method. Conserv Genet Resour 4(2):359-361

Evanno G, Regnaut S, Goudet J (2005) Detecting the number of clusters of individuals using the software structure: a simulation study. Mol Ecol 14:2611-2620

Excoffier L, Laval G, Schneider S (2006) Arlequin ver. 3.11: an integrated software package for population genetics data analysis. Computational and Molecular Population Genetics Lab, University of Berne, Switzerland

Felsenstein J (2005) PHYLIP (Phylogeny Inference Package) version 3.6. Distributed by the author. Department of Genome Sciences, University of Washington, Seattle

Fofana B, Vekemans X, Du Jardin E, Baudoin JP (1997) Genetic diversity in Lima bean (Phaseolus lunatus L.) as revealed by RAPD markers. Euphytica 95:157-165. doi:10.1023/A: 1002910114869 
Garza M, Bustos G, Izquierdo A (1996) Los Mayas: su tiempo antiguo. Universidad Autónoma de México, Instituto de Investigaciones Filológicas, Centro de Estudios Mayas, México

Gómez-Campo C (2006) Erosion of genetic resources within seed banks: the role of seed containers. Seed Sci Res 16:291-294. doi:10.1017/ssr2006260

González A, Wong A, Delgado-Salinas A, Papa R, Gepts P (2005) Assessment of inter simple sequence repeat markers to differentiate sympatric wild and domesticated populations of common bean. Crop Sci 45:606-615

Hamrick JL, Godt MJW, Murawski DA, Loveless MD (1991) Correlations between species traits and allozyme diversity: implications for conservation biology. In: Falk DA, Holsinger KE (eds) Genetics and conservation of rare plants. Oxford University Press, New York, pp 75-86

Krauss SL (2000) Accurate gene diversity estimates from amplified fragment length polymorphism (AFLP) markers. Mol Ecol 9:1241-1245

Kremer A, Caron H, Cavers S, Colpaert N, Gheysen L, Gribel R (2005) Monitoring genetic diversity in tropical trees with multilocus dominant markers. Heredity 95:274-280. doi:10.1038/sj.hdy.6800738

Lioi L, Lotti C, Galasso I (1998) Isozyme diversity, RFLP of the rDNA and phylogenetic affinities among cultivated Lima beans, Phaseolus lunatus (Fabaceae). Plant Syst Evol 213:153-164. doi:10.1007/BF00985196

Lynch M, Milligan BG (1994) Analysis of population genetic structure with RAPD markers. Mol Ecol 3:91-99

Maquet A, Zoro Bi I, Rocha OJ, Baudoin JP (1996) Case studies on breeding systems and its consequences for germplasm conservation. I. Isoenzyme diversity in wild Lima bean populations in Central Costa Rica. Genet Resour Crop Evol 43:309-318. doi:10.1007/BF00132950

Maquet A, Zoro Bi I, Delvaux M, Wathelet B, Baudoin JP (1997) Genetic structure of a Lima bean base collection using allozyme markers. Theor Appl Genet 95:980-991. doi:10.1007/s001220050651

Martínez-Castillo J (2005) Diversidad intraespecífica de Phaseolus lunatus L. e intensificación de la agricultura tradicional en la Península de Yucatán, México. Dissertation, Centro de Investigación Científica de Yucatán, México

Martínez-Castillo J, Zizumbo-Villarreal D, Perales-Rivera H, Colunga-GarcíaMarín P (2004) Intraspecific diversity and morpho-phenological variation in Phaseolus lunatus L. from the Yucatan Peninsula, México. Econ Bot 58(3):354-380

Martínez-Castillo J, Zizumbo-Villarreal D, Gepts P, ColungaGarcíamarín P (2007) Gene flow and genetic structure in the wild-weedy-domesticated complex of Phaseolus lunatus L. in its Mesoamerican center of domestication and diversity. Crop Sci 47:58-66. doi:10.2135/cropsci2006.04. 0241

Martínez-Castillo J, Colunga-GarcíaMarín P, Zizumbo-Villarreal D (2008) Genetic erosion and in situ conservation of Lima bean (Phaseolus lunatus L.) landraces in its Mesoamerican diversity center. Genet Resour Crop Evol 55:1065-1077. doi:10.1007/s10722-008-9314-1

Martínez-Castillo J, Camacho-Pérez L, Coello-Coello J, Andueza-Noh R (2012) Wholesale replacement of Lima bean (Phaseolus lunatus L.) landraces over the last
30 years in northeastern Campeche, Mexico. Genet Resour Crop Evol 59:191-204. doi:10.1007/s10722-011-9675-8

Martínez-Castillo J, Camacho-Pérez L, Villanueva-Viramontes S, Andueza-Noh RH, Chacón-Sánchez MI (2014) Genetic structure within the Mesoamerican gene pool of wild Phaseolus lunatus (Fabaceae) from Mexico as revealed by microsatellite markers: implications for conservation and the domestication of the species. Am J Bot 101(5):851-864. doi:10.3732/ajb.1300412

Martins M, Tenreiro R, Oliveira MM (2003) Genetic relatedness of Portuguese almond cultivars assessed by RAPD and ISSR markers. Plant Cell Rep 22:71-78

Miller A, Schaal B (2005) Domestication of a Mesoamerican cultivated fruit tree, Spondias purpurea. Proc Natl Acad Sci USA 36:12801-12806. doi:10.1073/pnas.0505447102

Montero-Rojas M, Ortiz M, Beaver JS, Siritunga S (2013) Genetic, morphological and cyanogen content evaluation of a new collection of Caribbean Lima bean (Phaseolus lunatus L.) landraces. Genet Resour Crop Evol 60:22412252. doi:10.1007/s10722-013-9989-9

Nienhuis J, Tivang J, Skroch P, Santos JB (1995) Genetic relationships among cultivars and landraces of Lima bean (Phaseolus lunatus L.) as measured by RAPD markers. J Am Soc Horticultur Sci 120:300-306

Page R (1996) TREEVIEW: an application to display phylogenetic trees on personal computers. Comput Appl Biosci 12:357-358. doi:10.1093/bioinformatics/12.4.357

Parzies H, Spoor W, Ennos R (2000) Genetic diversity of barley landraces accessions (Hordeum vulgaris ssp. vulgare) conserved for different lengths of time in ex situ gene banks. Heredity 84:476-486. doi:10.1046/j.1365-2540. 2000.00705.x

Peakall R, Smouse PE (2006) GenAlEx 6.5: genetic analysis in excel. Population genetic software for teaching and research-an update. Bioinformatics 28:2537-2539. doi:10. 1093/bioinformatics/bts460

Pritchard JK, Stephens M, Donnelly P (2000) Inference of population structure using multilocus genotype data. Genetics 155:945-959

Quiros CF, Ortega R, Van Raamsdonk LWD (1992) Amplification of potato genetic resources in their center of diversity: the role of natural outcrossing and selection by the Andean farmer. Genet Resour Crop Evol 39:107-113. doi:10.1007/BF00051229

Ranere A, Piperno D, Holst I, Dickau R, Iriarte J (2009) The cultural and chronological context of early Holocene maize and squash domestication in the central Balsas River Valley, Mexico. Proc Natl Acad Sci USA 106:5014-5018. doi:10.1073/pnas.0812590106

Ruz LA (1981) El pueblo maya. Salvat Mexicana, México, México

Serrano-Serrano ML, Hernandez-Torres J, Castillo-Villamizar G, Debouck DG, Chacón MI (2010) Gene pools in wild Lima bean (Phaseolus lunatus L.) from the Americas: evidences for an Andean origin and past migrations. Mol Phyl Evol 54:76-87. doi:10.1016/j.ympev.2009.08.028

Serrano-Serrano ML, Andueza-Noh RH, Martínez-Castillo J, Debouck DG, Chacón MI (2012) Evolution and domestication of Lima bean (Phaseolus lunatus L.) in Mexico: evidence from ribosomal DNA. Crop Sci 52:1698-1712. doi:10.2135/cropsci2011.12.0642 
Sharer R (1999) La civilización maya. Fondo de Cultura Económica, México

Slatkin M (1994) Gene flow and population structure. In: Real L (ed) Ecological genetics. Princeton University, New Jersey, p 238

Slatkin M, Barton NH (1989) A comparison of three indirect methods for estimating average levels of gene flow. Evolution 43:1349-1368

Spataro G, Tiranti B, Arcaleni P, Bellucci E, Attene G, Papa R, Spagnoletti ZP, Negri V (2011) Genetic diversity and structure of a worldwide collection of Phaseolus coccineus L. Theor Appl Genet 122:1281-1291. doi:10.1007/s00122011-1530-y

StatPoint, Inc. (2006). Statgraphics Centurión XV. Version 15.2.05 1982-2007

Vavilov NI (1926) Centers of origin of cultivated plants. Bul Appl Bot Genet Plant Breeding 16(2):248

Vekemans X (2002) AFLP-SURV version 1.0. Distributed by the author. Laboratoire de Génétique et Ecologie Végétale, Université Libre de Bruxelles, Belgium

Webster B, Lynch S, Tucker C (1979) A morphological study of the development of reproductive structures of Phaseolus lunatus L. J Am Soc Horticultur Sci 104:240-243
Yeh FC, Boyle TJ (1999) POPGENE v. 1.31. Microsoft Windows-based freeware for population analysis. University of Alberta and Centre for International Forestry Research, Edmonton

Zhivotovsky L (1999) Estimating population structure in diploids with multilocus dominant DNA markers. Mol Ecol 8:907-913. doi:10.1046/j.1365-294x.1999.00620.x

Zietkiewicz E, Rafalski A, Labuda D (1994) Genome fingerpriting by simple sequence repeat (SSR) - anchored polymerase chain reaction amplification. Genomics 20:176-183. doi:10.1006/geno.1994.1151

Zizumbo-Villarreal D, Colunga Garcia-Marín P (2010) Origin of agriculture and plant domestication in West Mesoamerica. Genet Resour Crop Evol 57:813-825. doi:10.1007/s10722-009-9521-4

Zizumbo-Villarreal D, Colunga-GarcíaMarín P, Payro E, Delgado-Valerio P, Gepts P (2005) Population structure and evolution dynamics of wild-weedy-domesticated complexes of common bean in a Mesoamerican region. Crop Sci 45:1073-1083. doi:10.2135/cropsci2004.0340 